Gut, 1972, 13, 709-712

\title{
Effect of cholecystokinin-pancreozymin and secretin on the volume, composition, and enzymatic activity of hepatic bile in rabbits
}

\author{
S. KIRCHMAYER ${ }^{1}$, A. TARNAWSKI, H. DROŻDŻ, AND K. CICHECKA \\ From the Department of Gastroenterology, Institute of Internal Medicine, Medical Academy, Cracow, and the \\ Department of General and Experimental Pathology, Medical Academy, Cracow, Poland
}

SUMMARY In rabbits given cholecystokinin-pancreozymin intravenously a statistically significant increase in bile volume and alkaline phosphatase (AP) activity was observed. There was also an increase in the total amount of protein, cholesterol, bicarbonates $\mathrm{Na}, \mathrm{K}, \mathrm{Ca}, \mathrm{Mg}$, and the total activity of alkaline phosphatase and leucineaminopeptidase (LAP) secreted in bile within 90 minutes after pancreozymin injection. Pancreozymin had no effect on the concentration and output of taurocholates and the activity of gammaglutamyltranspeptidase (GGTP) and alanineaminotransferase (ALAT) in bile. Secretin neither changes the volume nor the concentration of any of the investigated components in rabbit bile.

Secretin not only increases the flow of bile from the liver but also its bicarbonate concentration in man (Grossman, Janowitz, Ralston, and Kim, 1949; Jorpes, Mutt, Jonson, Thulin, and Sundman, 1963; Konturek, Dabrowski, Adamczyk, and Kulpa, 1969; Waitman, Dyck, and Janowitz, 1969), pig (Hardison and Norman, 1968), dog (Jones and Grossman, 1939; Preisig, Cooper, and Wheeler, 1962; Soloway, Clark, Senior, and Brooks, 1969; Wheeler and Mancusi-Ungaro, 1966; Wheeler, Ross, and Bradley, 1968), and also in cats and guinea pigs (Scratcherd, 1965). In the rabbit on the other hand secretin is without effect. Although the cholecystokinetic effect of cholecystokinin-pancreozymin is well documented there is little information concerning its effect on the flow of bile and its clinical composition after the gall bladder has been surgically excluded from the remainder of the biliary system (Jorpes, Mutt, Jonson, Thulin, and Sundman, 1965).

The present study was carried out with the object of investigating the effects of cholecystokininpancreozymin and secretin on the volume and composition of the bile in the rabbit.

\section{Method}

The experiments were carried out on 45 male rabbits Received for publication 18 May 1972.

${ }^{1}$ Please request reprints from Dr S. Kirchmayer. Gastroenterological Unit, Medical Academy, Krakow, al Ropernika 15, Poland. of average weight $3.03 \mathrm{~kg}$. Twenty-four hours before the experiment the animals were denied food. They were anaesthetized with $20 \%$ urethane solution given intravenously in doses of $1.0 \mathrm{~g} / \mathrm{kg}$ body weight. The cystic duct was tied and the common bile duct cannulated with a polyethylene tube of $1.2 \mathrm{~mm}$ inner diameter. Animals in which blood contaminated the bile were eliminated from the experiment. Remaining animals were divided into three groups. In 12 control animals $2.5 \mathrm{ml} 0.9 \% \mathrm{NaCl}$ solution was given intravenously. In the second group of 12 rabbits secretin (Sigma 77 B 00/0) was given intravenously in the dose 5 Crick-Harper-Raper units/kg body weight dissolved in $0.9 \% \mathrm{NaCl}$ to total volume $2.5 \mathrm{ml}$. The third group of 12 rabbits received a similarly dissolved solution of cholecystokinin-pancreozymin (Sigma 78 B 1670), 8 Crick-Harper-Raper units/kg body weight. The bile was collected for 90 minutes after the end of the intravenous injection. The total volume secreted within 90 minutes was measured in a precise graduated cylinder. $p \mathrm{H}$ was tested in a LBS pH meter, protein contents by Lowry's method according to Daughaday, Lowry, Rosenbrough, and Fields (1952), cholesterol by the method of Chiamori and Henry (1959), bicarbonates by titration, magnesium by the method of Natelson (1957), chlorides by the mercurometric method of Donnerberg (1960), and sodium, potassium, and calcium were determined by flame photometry. The concentration of bile acids measured as taurocholates was calculated 
from 'anion deficit' (Waitman et al, 1969). The activity of AP in bile was determined by the method of Bodansky (1933), of LAP by the method of Goldbarg and Rutenburg (1958), of GGTP by the method of Orlowski and Szewczuk (1962), and of ALAT by the method of Wróblewski and Cabaud (1957). The results thus obtained were statistically analysed with the Student $t$ test.

\section{Results}

Average values of bile volume, $p \mathrm{H}$, concentration of the investigated components, and enzyme activities are given in Tables I and III.

Mean values of the total amounts of investigated components and total activities of the enzymes secreted in bile during 90 minutes are shown in

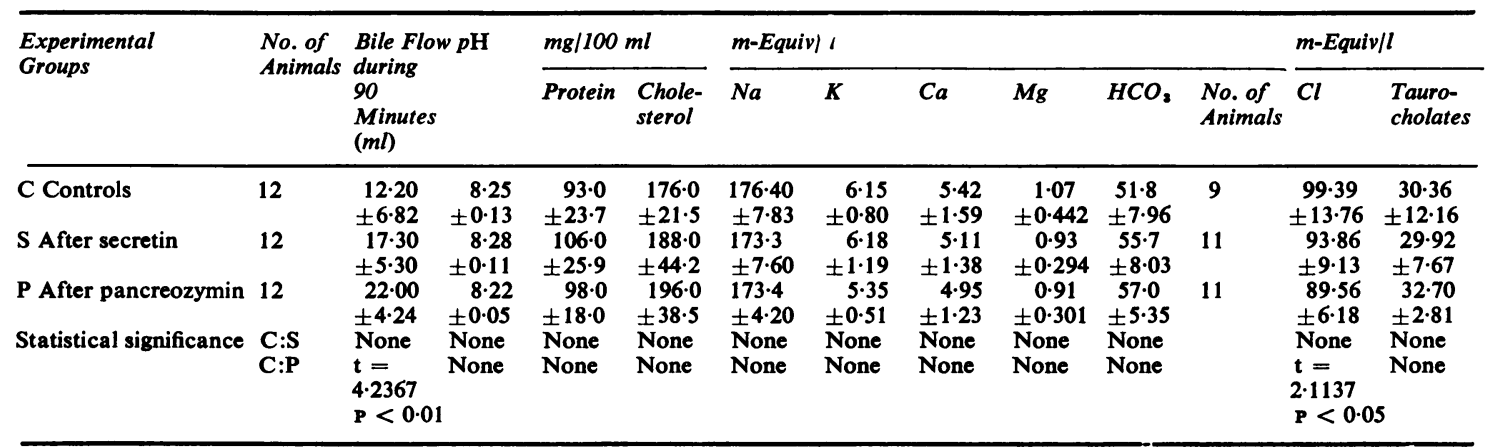

Table I Average of volume, $\mathrm{pH}$, and concentration of components in bile

\begin{tabular}{|c|c|c|c|c|c|c|c|c|c|c|c|}
\hline \multirow[t]{2}{*}{$\begin{array}{l}\text { Experimental } \\
\text { Groups }\end{array}$} & \multirow[t]{2}{*}{$\begin{array}{l}\text { No. of } \\
\text { Animals }\end{array}$} & \multicolumn{2}{|c|}{ mg/90 Minutes } & \multirow{2}{*}{$\begin{array}{l}\begin{array}{l}\text { m-Equiv } / l \\
90 \text { Minutes }\end{array} \\
\mathrm{Na}\end{array}$} & \multicolumn{3}{|c|}{${ }_{s}^{\mu-E q u i v / 90 ~ M i n u t e s}$} & \multirow{2}{*}{$\begin{array}{l}\text { m-Equiv/l } \\
90 \text { Minutes } \\
\mathrm{HCO}_{3}\end{array}$} & \multirow[t]{2}{*}{$\begin{array}{l}\text { No. of } \\
\text { s Animals }\end{array}$} & \multicolumn{2}{|c|}{ m-Equiv/90 Minutes } \\
\hline & & Protein & $\begin{array}{l}\text { Choles- } \\
\text { terol }\end{array}$ & & $\boldsymbol{K}$ & $\mathrm{Ca}$ & $M g$ & & & $C l$ & $\begin{array}{l}\text { Tauro- } \\
\text { cholates }\end{array}$ \\
\hline C Controls & 12 & $10 \cdot 20$ & $22 \cdot 10$ & $2 \cdot 16$ & $74 \cdot 1$ & $60 \cdot 4$ & $12 \cdot 5$ & 0.645 & $\begin{array}{l}9 \\
9\end{array}$ & $1 \cdot 317$ & 0.485 \\
\hline $\begin{array}{l}\text { S After } \\
\text { secretin }\end{array}$ & 12 & $\begin{array}{r} \pm 4 \cdot 02 \\
17 \cdot 80\end{array}$ & $\begin{array}{l} \pm 13 \cdot 1 \\
31 \cdot 80\end{array}$ & $\begin{array}{r} \pm 1 \cdot 23 \\
3 \cdot 02\end{array}$ & $\begin{array}{c} \pm 43.50 \\
106.3\end{array}$ & $\begin{array}{c} \pm 29.97 \\
86.6\end{array}$ & $\begin{array}{l} \pm 6 \cdot 29 \\
16 \cdot 3\end{array}$ & $\begin{array}{r} \pm 0.394 \\
0.944\end{array}$ & 11 & $\begin{array}{r} \pm 0.47 \\
1.567\end{array}$ & $\begin{array}{r} \pm 0.438 \\
0.523\end{array}$ \\
\hline $\begin{array}{l}\text { P After } \\
\text { pancreozymin }\end{array}$ & 12 & $\begin{array}{r} \pm 4 \cdot 63 \\
21 \cdot 42\end{array}$ & $\begin{array}{r} \pm 9 \cdot 94 \\
42 \cdot 70\end{array}$ & $\begin{array}{r} \pm 0.98 \\
3.81\end{array}$ & $\begin{array}{r} \pm 36 \cdot 3 \\
118 \cdot 0\end{array}$ & $\begin{array}{l} \pm 29 \cdot 79 \\
105 \cdot 7\end{array}$ & $\begin{array}{r} \pm 7 \cdot 87 \\
20 \cdot 35\end{array}$ & $\begin{array}{r} \pm 0.484 \\
1 \cdot 260\end{array}$ & 11 & $\begin{array}{r} \pm 0.49 \\
1.997\end{array}$ & $\begin{array}{r} \pm 0.260 \\
0.730\end{array}$ \\
\hline $\begin{array}{l}\text { Statistical } \\
\text { significance }\end{array}$ & $\begin{array}{l}C: S \\
C: P\end{array}$ & $\begin{array}{l} \pm 5.07 \\
t=4.182 \\
P<0.01 \\
t=5.807 \\
P<0.01\end{array}$ & $\begin{array}{l} \pm 10.70 \\
\text { None } \\
t=4.261 \\
P<0.01\end{array}$ & $\begin{array}{l}\begin{array}{l} \pm 0.72 \\
\text { None }\end{array} \\
t=4.040 \\
P<0.01\end{array}$ & $\begin{array}{l} \pm 28.4 \\
\text { None } \\
t=3.11 \\
P<0.01\end{array}$ & $\begin{array}{l} \pm 23.16 \\
t=2.155 \\
P<0.05 \\
t=4 \cdot 163 \\
P<0.01\end{array}$ & $\begin{array}{l}\begin{array}{l} \pm 9.52 \\
\text { None }\end{array} \\
t=2.220 \\
P<0.05\end{array}$ & $\begin{array}{l}\stackrel{ \pm 0.310}{\text { None }} \\
t=4.310 \\
P<0.01\end{array}$ & & $\begin{array}{l}\quad \begin{array}{c} \pm 0.38 \\
\text { None }\end{array} \\
t=3.575 \\
P<0.01\end{array}$ & $\begin{array}{l} \pm 0 \cdot 137 \\
\text { None }\end{array}$ \\
\hline
\end{tabular}

Table II Average of total output of components secreted in bile during 90 minutes

\begin{tabular}{|c|c|c|c|c|c|c|}
\hline Experimental Groups & $\begin{array}{l}\text { No. of } \\
\text { Animals }\end{array}$ & $A P$ & $L A P$ & $G G T P$ & $\begin{array}{l}\text { No. of } \\
\text { Animals }\end{array}$ & $A L A T$ \\
\hline C Controls & 12 & $18 \cdot 4$ & 1.41 & $4 \cdot 70$ & 7 & $11 \cdot 3$ \\
\hline S After & 12 & $\begin{array}{c} \pm 20.07 \\
36 \cdot 5\end{array}$ & $\begin{array}{l} \pm 0.381 \\
1.34\end{array}$ & $\begin{array}{r} \pm 3.43 \\
5.30\end{array}$ & $\gamma$ & $\begin{array}{l} \pm 5 \\
19 \cdot 0\end{array}$ \\
\hline $\begin{array}{l}\text { secretin } \\
\text { P After }\end{array}$ & 12 & $\begin{array}{c} \pm 26.04 \\
48.3\end{array}$ & $\begin{array}{l} \pm 0.317 \\
1 \cdot 50\end{array}$ & $\begin{array}{r} \pm 3.93 \\
2.90\end{array}$ & 6 & $\begin{array}{c} \pm 17 \cdot 61 \\
13 \cdot 3\end{array}$ \\
\hline pancreozymin & 12 & & & & 12 & \\
\hline $\begin{array}{l}\text { Statistical } \\
\quad \text { significance }\end{array}$ & $\begin{array}{l}\text { C:S } \\
\text { C:P }\end{array}$ & $\begin{array}{l} \pm 39.72 \\
\text { None } \\
t=2.3275 \\
P<0.05\end{array}$ & $\begin{array}{l} \pm 0.753 \\
\text { None } \\
\text { None }\end{array}$ & $\begin{array}{l} \pm 2 \cdot 55 \\
\text { None } \\
\text { None }\end{array}$ & & $\begin{array}{l} \pm 14 \cdot 03 \\
\text { None } \\
\text { None }\end{array}$ \\
\hline
\end{tabular}

Table III Average of enzyme activities in bile ( $m U$ per $m l)$ 


\begin{tabular}{|c|c|c|c|c|c|c|}
\hline Experimental Groups & $\begin{array}{l}\text { No. of } \\
\text { Animals }\end{array}$ & $A P$ & $L A P$ & GGTP & $\begin{array}{l}\text { No. of } \\
\text { Animals }\end{array}$ & $A L A T$ \\
\hline C Controls & 12 & $148 \cdot 20$ & $17 \cdot 25$ & $37 \cdot 70$ & 7 & $177 \cdot 4$ \\
\hline S After & & $\begin{array}{r} \pm 111 \cdot 21 \\
630 \cdot 10\end{array}$ & $\begin{array}{r} \pm 12.68 \\
24.00\end{array}$ & $\begin{array}{r} \pm 12 \cdot 51 \\
90 \cdot 80\end{array}$ & & $\begin{array}{r} \pm 127 \cdot 3 \\
232 \cdot 3\end{array}$ \\
\hline $\begin{array}{l}\text { secretin } \\
\text { P After }\end{array}$ & 12 & $\begin{array}{r}+626 \cdot 20 \\
1061 \cdot 00\end{array}$ & $\begin{array}{r} \pm 9.45 \\
31 \cdot 90\end{array}$ & $\begin{array}{r}69 \cdot 89 \\
63 \cdot 10\end{array}$ & 6 & $\begin{array}{r}165 \cdot 4 \\
304 \cdot 0\end{array}$ \\
\hline pancreozymin & 12 & & & & 12 & \\
\hline $\begin{array}{l}\text { Statistical } \\
\text { significance }\end{array}$ & $\begin{array}{l}C: S \\
C: P\end{array}$ & $\begin{array}{l} \pm 759.16 \\
t=2.6204 \\
P<0.05 \\
t=3.7714 \\
P<0.01\end{array}$ & $\begin{array}{l} \pm 17.91 \\
\text { None } \\
t=2.3118 \\
P<0.05\end{array}$ & $\begin{array}{l} \pm 54.26 \\
\mathrm{t}=2.5959 \\
\mathrm{P}<0.05 \\
\text { None }\end{array}$ & & $\begin{array}{l} \pm 316 \cdot 4 \\
\text { None } \\
\text { None }\end{array}$ \\
\hline
\end{tabular}

Table IV Average of total activity of enzymes secreted with bile during 90 minutes ( $m U$ per 90 minutes)

Tables II and IV and are expressed in mg, $\mu$-equiv, $\mathrm{m}$-equiv, and $\mathrm{mU} /$ per 90 minutes.

As can be seen in the Tables no distinct changes were observed after secretin in $p \mathrm{H}$, the cholesterol, $\mathrm{Na}, \mathrm{K}, \mathrm{Ca}, \mathrm{Mg}, \mathrm{Cl}$, protein, bicarbonates, and taurocholates concentration as well as in AP, LAP, GGTP, and ALAT activities when compared with the control group. However, after cholecystokininpancreozymin administration a statistically significant increase in the bile volume and AP activity occurred. At the same time chloride concentration decreased. Cholecystokinin-pancreozymin increased significantly the total output of all of the investigated components secreted into the bile during 90 minutes with the exception of taurocholates and GGTP and ALAT.

\section{Discussion}

It has been assumed that bile is formed in two phases, according to Boyer and Klatskin (1970), Brooks (1969), Erlinger, Dumont, Dhumeaux, and Benhamou (1969), Sherlock (1968), Wheeler (1965) and Wheeler et al (1968), and that the first phase depends on the active transport of bile salts from hepatocytes into the lumen of the biliary canaliculi. As a result of osmotic and possible electrical potential differences water and cations would be expected to follow passively Boyer and Klatskin (1970) and Erlinger et al (1969), propose that bile is produced and secreted in this phase in two fractions: one fraction is bile salt dependent and is determined by the active transport of bile salts whereas the second fraction is independent of bile salt transport and occurs as the result of active transport of electrolytes from hepatocytes into biliary canaliculi.

In the second phase alteration in the volume and composition of the bile occurs from the level of the intralobular ducts to the common duct, by a process of active bicarbonate transport and reabsorption of water and electrolytes. The choleretic effects of secretin have been attributable to the effect of the hormone on the distal ducts by stimulating the secretion of bicarbonate. The absence of an effect of secretin confirms the work of Scratcherd (1965), and the choleretic effect of cholecystokinin-pancreozymin affecting the electrolyte compound only would suggest a distal site of action for this hormone in rabbits also, being similar to the choleretic effect of secretin in other species. The site of action of cholecystokinin-pancreozymin cannot, however, be determined with certainty from these studies.

The increase in alkaline phosphatase activity in bile after pancreozymin may be the result of release of the enzyme either from hepatocyte or the epithelium of the bile duct or from both sources. The first possibility is supported by the work of LeVeen, Talbot, Restuccia, and Barberio (1950) but on work presented in this paper neither the site of action nor the mechanism of action of cholecystokinin-pancreozymin can be satisfactorily interpreted. The effects of cholecystokinin-pancreozymin on the alteration in enzyme concentration and output in bile is the subject of further experimental and clinical observations.

We are most grateful to Dr T. Scratcherd for his generosity in virtually rewriting our paper in English.

References

Bodansky, A. (1933). Phosphatase studies. Determination of serum phosphatase factors influencing the accuracy of the determination. J. biol. Chem., 101, 93-104.

Boyer, J. L., and Klatskin, G. (1970). Canalicular bile flow and bile secretory pressure: evidence for a non-bile salt dependent fraction in the isolated perfused rat liver. Gastroenterology, 59, 853-859.

Brooks, F. P. (1969). The secretion of bile. Amer. J. dig. Dis., 14, 343349.

Chiamori, N., and Henry, R. J. (1959). Study of the ferric chloride method for determination of total cholesterol and cholesterol esters. Amer. J. clin. Path., 31, 305-309.

Daughaday, W. H., Lowry, O. H., Rosenbrough, N. J., and Fields, W. S. (1952). Determination of cerebrospinal fluid protein with the Folin fenol reagent. J. Lab. clin. Med., 39, 663-665. 
Donnerberg, E. (1960). Automatische merkurimetrische Chloridbestimmung im Serum und Harn. Arztl. Lab., 6, 134.

Erlinger, S., Dumont, M., Dhumeaux, D., and Benhamou, H. P. (1969). Bile secretion in the rabbit: evidence for a large hepatocytic bile salt-independent fraction. (Abstr.). Gastroenterology, 56, 1213.

Goldbarg, J. A., and Rutenburg, A. M. (1958). The colorimetric determination of leucineaminopeptidase in urine and serum of normal subjects and patients with cancer and other diseases. Cancer (Philad.), 11, 283-291.

Grossman, M. I., Janowitz, H. D., Ralston, H. K., and Kim, S. (1949). The effect of secretin on bile formation in man. Gastroenterology, 12, 133-138.

Hardison, W. G. M., and Norman, J. C. (1968). Electrolyte composition of the secretin fraction of bile from the perfused pig liver. Amer. J. Physiol., 214, 758-763.

Jones, R. S., and Grossman, M. I. (1969). Choleretic effects of secretin and histamine in the dog. Amer. J. Physiol., 217, 532-535.

Jorpes, J. E., Mutt, V., Jonson, G., Thulin, L., and Sundman, L. (1963) The effect of secretin on bile flow. Gastroenterology, 45, 786788.

Jorpes, E., Mutt, V., Jonson, G., Thulin, L., and Sundman, L. (1965). The influence of secretin and cholecystokinin on bile flow. In The Biliary System, edited by W. Taylor, pp. 293-301. Blackwell, Oxford.

Konturek, S. J., Dabrowski, A., Adamczyk, B., and Kulpa, J. (1969). The effect of secretin, gastrin-pentapeptide and histamine on gastric acid and hepatic bile secretion in man. Amer.J. dig. Dis. $14,900-907$.

LeVeen, H. H., Talbot, L. J., Restuccia, M., and Barberio, J. R. (1950). Metabolism and excretion of alkaline phosphatase: relation to liver function and determination of maximum secretory rates of the liver. J. Lab. clin. Med., 36, 192-205.
Natelson, S. (1957). Microtechniques of Clinical Chemistry for the Routine Laboratory, p. 26. Thomas, Springfield, Illinois.

Orlowski, M., and Szewczuk, A. (1962). Determination of $\gamma$-glutamyl transpeptidase activity in human serum and urine. Clin. chim. Acta, 7, 755-760.

Preisig, R., Cooper, H. L., and Wheeler, H. O. (1962). The relationship between taurocholate secretion rate and bile production in the unanesthetized dog during cholinergic blockade and during secretin administration. J. clin. Invest., 41, 1152-1162.

Scratcherd, T. (1965). Electrolyte composition and control of biliary secretion in the cat and rabbit. In The Biliary System, edited by W. Taylor, pp. 515-529. Blackwell, Oxford.

Sherlock, S. (1968). Disease of the Liver and Biliary System, 4th ed. Blackwell, Oxford.

Soloway, R. D., Clark, M. L., Senior, J. R., and Brooks, F. P. (1969). Effect of secretin on the flow and composition of bile. (Abstr.). Gastroenterology, 56, 1263.

Waitman, A. M., Dyck, W. P., and Janowitz, H. D. (1969). Effect of secretin and acetazolamide on the volume and electrolyte composition of hepatic bile in man. Gastroenterology, 56, 286294.

Wheeler, H. O. (1965). Inorganic ions in bile. In The Biliary System, edited by W. Taylor, pp. 481-493. Blackwell, Oxford.

Wheeler, H. O., and Mancusi-Ungaro, P. L. (1966). Role of bile ducts during secretin choleresis in dogs. Amer. J. Physiol., 210, 1153-1159.

Wheeler, H. O., Ross, E. D., and Bradley, S. E. (1968). Canalicular bile production in dogs. Amer. J. Physiol., 214, 866-874.

Wróblewski, F., and Cabaud, P. (1957). Colorimetric measurement of serum glutamic pyruvic transaminase. Amer. J. clin. Path., 27, 235-239. 